\title{
UMA REFLEXÃO SOBRE A DISCRICIONARIEDADE JUDICIAL ATRAVÉS DA HISTÓRIA DO DIREITO PENAL: AS PUNIÇÕES ARBITRÁRIAS NO OCASO DO ANTIGO REGIME
}

A REFLECTION ON JUDICIAL DISCRETIONARY THROUGH THE HISTORY OF CRIMINAL LAW: ARBITRARY PUNISHMENTS AT THE OCCASION OF THE OLD REGIME

Sílvia Alves ${ }^{1}$

Universidade de Lisboa

\section{Resumo}

O arbítrio dos juízes não viveu num território estranho ao direito e floresceu sob o império da lei. Sua investigação histórica, que é um dos pontos mais relevantes da formação do direito penal, é o objeto dessa investigação.

Palavras-chaves

Discricionariedade judicial. Antigo regime. Direito Penal.

\section{Abstract}

The arbiters of the judges did not live in a territory alien to the law and flourished under the rule of law. His historical investigation, which is one of the most relevant points in the formation of criminal law, is the object of this investigation. Keywords Judicial discretion. Old regime. Criminal Law.

1. Novidade para uma tartaruga bicentenária

«O iluminismo penal teve uma função determinante para a cientificidade do direito penal, mas não se pode reduzir o método penal ao que pretendiam os referidos iluministas.» (BRANDÃO, 2012 p.198)

\footnotetext{
${ }^{1}$ Professora da Faculdade de Direito da Universidade de Lisboa
} 
«Uma época que identifica o direito com a lei e esta com a vontade do legislador, assim como uma conceção instrumental do direito ou uma conceção para a qual valem mais a segurança jurídica e a calculabilidade das resoluções do que a justiça, propende a reduzir a faculdade do juiz em relação à interpretação das leis e a negar o desenvolvimento aberto do direito.» (LARENZ, 2005, p.521)

a. A centralidade da interpretação jurídica e da decisão judicial nos debates jus-filosóficos contemporâneos pode ter sido recebida como uma novidade refrescante e libertadora que eclodiu com sucesso porque foi semeada em terreno fértil; crises da mais variada ordem e respostas insuficientes por parte dos legisladores e dos governos. Contudo, a consciência de que a forma de operar dos juristas não se esgota em puras operações de lógica formal tem pouco de inovador se alongarmos a perspetiva histórica. A metodologia jurídica, tal como tem sido entendida na época contemporânea, parece vetusta, mas tem somente a idade de uma tartaruga bicentenária (HESPANHA, 2012, p.522). Essa ilusão de novidade serviu para romper e tentar superar um certo positivismo, colocando-nos num tempo de transição, que ainda não se definiu com clareza, a "pós-modernidade". Um tempo que parece estar para além do jusnaturalismo e do positivismo. Ser jusnaturalista pura e simplesmente não está na moda. E nem sequer ser positivista. Esta terra de ninguém pode configurar-se como uma síntese compromissória ou um pluralismo, na visão de Arthur Kaufmann (1923-2001). Ou pode assumir a forma de uma negação através de um conceito não positivista de direito, como no pensamento de Robert Alexy (1945-).

«Não se trata de acusar a teoria analítica do direito (isso seria altamente irrazoável); só se exige que esta se torne consciente do seu carácter unilateral e adquira por isso a compreensão de que deve comunicar-se com outras tendências, especialmente a hermenêutica. A hermenêutica requer a analítica pois, sem esta, seria cega. Mas, por outro lado, necessita também a 
analítica da hermenêutica pois sem esta aquela seria vazia. Eu advogo um pluralismo na ciência e na filosofia.» (KAUFMANN, 2007, p.17)

«Normas individuais estabelecidas em conformidade com o ordenamento jurídico perdem a validade jurídica quando não apresentam um mínimo de eficácia social ou de possibilidade de eficácia e/ou quando são extremamente injustas. Esta última restrição volta a exprimir o caráter não positivista do direito aqui apresentado.» (ALEXY, 2009, p.154)

A rutura com uma ars inveniendi secular, com uma metodologia geneticamente problemática (ALBUQUERQUE, 2004, p.303) foi emberçada na segunda metade do século XVIII e concretizou-se no século da codificação. Antes e durante muitos séculos, o ius e a realização judiciária da aequitas conviveram harmónica e pacificamente. A justiça era também tarefa dos juristas e assim seria até o prudente (prudens) se transformar num legista burocrático (ALBUQUERQUE, 2004, p.15).

«O que é a justiça? Não, não pode ser igualdade, sonho longínquo, sonho inconstante, sonho falso se referida à partilha dos bens temporais. Mas uma proporção - igualdade geométrica, diz Aristóteles. Qual? Qual é a sua fórmula? Eu respondo que não a temos, e que se trata de uma adaptação perpétua - que é esse o trabalho do jurista, procurá-la em cada caso sem ter previamente a fórmula, mas esses mapas provisórios e imperfeitos que são as leis.» (VILLEY, 1995, p.219)

Com o racionalismo, a ideia de progresso invade o direito, abandonando-se o modelo romano, a ratio scripta, que parecia transcender o tempo e o espaço. O século das Luzes é por isso, sem surpresa, anti-romanista e sobretudo abomina o direito dos prudentes e a torrente das opiniões, a errante instabilidade das interpretações (BECCARIA, 1998, pp.68 e 69). Aspira a um direito certo e seguro, desenhado a régua e esquadro. No discurso da época, deseja um 
catecismo, acessível aos seus destinatários. Todas as expectativas são depositadas na lei. É o tempo do reformismo e da ciência da legislação.

«É mais fácil descrever uma curva do que uma linha reta. A geometria oferece muitas regras para desenhar uma linha perpendicular: a pintura, a escultura e a arquitetura definem princípios certos, fora dos quais não se encontra exatidão: sem a observância de uma regra, a linha reta que se pretende descrever degenerará facilmente numa curva (...) A natureza do homem é portanto incompatível com uma perfeição arbitrária. Cada ciência deve ter regras e, à medida que essas regras são aperfeiçoadas, os conhecimentos humanos melhoram. Será a ciência da legislação exceção a um princípio tão universal e constante?» (FILANGIERI, 1864, pp.70 e 71)

Qual o fundamento dessa confiança na santidade das leis ditadas por aquele que não encontra na terra quem se the assemelhe pois foi feito para não ter medo (Livro de Job, 42, 24)? Qual a razão que conduz à substituição da auctoritas pela potestas?

«Non est potestas super terram quae comparetur ei» [Não há sobre a terra poder que se lhe possa comparar] (frontispício da primeira edição da obra maior de Hobbes, o Leviatã, de1651)

O genebrino (1712-1778) enuncia no Contrato Social (1762) o brocardo que ecoará no século da exegese: as leis, que são o produto da vontade geral, não podem ser injustas porque ninguém é injusto consigo mesmo (ROUSSEAU, 1762, p.78). Como lembraria John Austin (1790-1859), Hobbes (1588-1679) deixara já claro que nenhuma lei (positiva) podia ser (juridicamente) injusta, desenhando um relativismo que conduziria a uma irremediável desvalorização do conteúdo do direito.

«Nos seus magistrais tratados políticos, Hobbes afirmou que 'nenhuma lei pode ser injusta' [no law can be unjust], afirmação que muitos consideraram um paradoxo imoral e perigoso. Contudo, se olharmos a finalidade dos tratados em que aparece, ou também as passagens que a seguem imediatamente, dar-nos-emos conta de que a afirmação não é paradoxal nem perigosa, mas um truísmo formulado de modo imprudente. 
Obviamente, o seu significado é este: 'nenhuma lei positiva é juridicamente injusta' [no positive law is legally unjust].» (AUSTIN, 1832, p.276)

«Fortuna do sistema de Hobbes. - A teoria do direito de Hobbes traz consigo uma Revolução. Enquanto o seu programa político, favorável ao absolutismo, não encontrou poucos adversários no círculo dos 'filósofos' modernos, o esquema central do sistema, a crítica de Aristóteles, a negação da 'natureza política' do homem, a artificialidade do direito, a sua redução ao texto da lei - e também a libertação da tradição clerical - viriam a ter uma tal fortuna que ainda carregamos o seu peso.» (VILLEY, 2006, p.110)

No Espírito das Leis (1748), a aversão ao arbítrio judiciário leva Montesquieu (1689-1755) a reduzir os juízes da nação à boca que pronuncia as palavras da lei, seres inanimados impedidos de moderar a sua força e o seu rigor (MONTESQUIEU, 1748, p.256). Beccaria (1738-1794) remata sem equívocos esta evolução: a interpretação das leis é um mal e a obscuridade das leis, que arrasta consigo necessariamente a interpretação, outro.

«O poder de interpretar as leis penais também não pode recair sobre os juízes criminais pela simples razão de que eles não são legisladores. (...) Não há coisa mais perigosa do que aquele axioma comum que obriga a consultar o espírito da lei. É uma brecha aberta à torrente das opiniões.» (BECCARIA, 1998, pp.68 e 69)

O espírito da lei não podia ser o resultado da boa ou má lógica de um juiz, de uma fácil ou nociva digestão. Como poderia a sorte de um cidadão depender do ocasional fermento dos humores de um juiz (BECCARIA, 1998, p.69)?

«Para qualquer delito deve o juiz construir um silogismo perfeito: a premissa maior deve ser a lei geral; a menor, a ação conforme ou não à lei; a conclusão, a liberdade ou a pena.» (BECCARIA, 1998, p.68)

O reformismo de setecentos define as máximas que despontarão no século seguinte: hegemonia da lei; perigosidade da interpretação; e neutralidade do juiz.

b. Assim como a consciência da natureza criativa da interpretação e da aplicação do direito está longe de constituir uma 
novidade "pós-moderna" mas antes a ancestral história dos juristas, também durante o predomínio dos positivismos essa verdade não deixou de emergir e de ser sucessivamente lembrada.

Não foi necessário esperar pela livre investigação científica do direito de François Gény (1861-1938) para o próprio Jean-ÉtienneMarie Portalis (1746-1807), redator do Code Civil des Français (1804), reconhecer, no Discurso preliminar sobre o projeto de Código Civil (1801), a natural insuficiência da legislação e a necessidade de completar o santuário das leis com um depósito de máximas, de decisões e de doutrina que se apura quotidianamente pela prática e pela discussão das disputas judiciárias (PORTALIS, 1844, p.8). Na ausência de lei, consultava-se o uso ou a equidade, definida como $o$ regresso à lei natural, no silêncio, oposição ou obscuridade das leis positivas (p.13).

«Na abertura das nossas conferências, fomos criticados pela opinião, tão geralmente difundida, segundo a qual, na redação de um código civil, alguns textos bem precisos sobre determinada matéria podem ser suficientes, e que a grande arte é a de simplificar tudo prevendo tudo.

Tudo simplificar é uma operação sobre a qual é necessário que nos entendamos. Tudo preveré um objetivo impossível de atingir.» (PORTALIS, 1844, pp.5 e 6)

Para a escola histórica do direito, o direito popular, que nascia e se desenvolvia espontaneamente e jamais em virtude do arbítrio do legislador, acabava por tomar um ar científico e tornar-se matéria da competência dos juristas, que representavam então o povo (SAVIGNY, 1918, p.12). Eles reconheciam e reconstruíam a sistematicidade inerente ao direito, enquanto todo orgânico ou manifestação do espírito do povo (Volksgeist). O direito do povo (Volksrecht) transforma-se então num direito dos professores (Professorenrecht) e 
a invenção do direito volta a ser, deste modo, uma hermenêutica, uma interpretação (HESPANHA, 2012, p.441).

Herman Kantorowicz (1877-1940) usa de tal moderação no seu manifesto A Luta pela Ciência do Direito (1906) que, olhado a partir dos nossos dias, mal se pode perceber o escândalo que provocou (KANTOROWICZ, 1949, p.364). Afinal, não considerava que a jurisdição é principalmente, e deveria continuar a ser, missão do Estado? Com modéstia, reconhece a falta de unidade num movimento que, como qualquer jovem, não sabe com exatidão o que quer. Mas sobretudo é absolutamente certeiro quando prognostica que, devido à falta de compreensão da história, o movimento do direito livre parece radical e está condenado ao insucesso. Definindo as suas frentes de batalha e colocando no extremo oposto a jurisprudência dos conceitos, a obediência inteligente da jurisprudência dos interesses acabaria por triunfar. O pseudónimo Gnaeus Flavius recorda que o jurista burocrata pertence à decadência romana e tropeça nessa qualidade desagradável da jurisprudência, a sua mania das grandezas (p.339); na verdade, a lei tem tantas lacunas como palavras e unicamente o direito livre (freies Recht), com a espontaneidade das suas decisões e a plasticidade emotiva do seu conteúdo face ao caso concreto, poderia integrar as lacunas. E, de facto, sempre o tinha feito (p.337). Uma vez que não se conferia ao juiz mais do que ele mesmo necessariamente reivindicava para si, não seria preferível admitir o seu potencial criativo, em vez de chegar ao mesmo resultado através de um "caminho de contrabandista" (p.364)?

O normativismo de Hans Kelsen (1881-1973) destaca também a função normativa da decisão judicial. A sentença é mais uma norma jurídica dentro da estrutura escalonada do ordenamento. A norma hierarquicamente superior define uma moldura e, portanto, os limites de atuação do juiz. Mas simultaneamente delimita o território de uma 
escolha que significa criação de direito: a norma jurídica geral é sempre uma simples moldura dentro da qual há-de ser produzida a norma jurídica individual (KELSEN, 1984, p.337). Na medida em que escolhe um resultado interpretativo em detrimento de outro, o juiz aplica $e$ cria direito. A sua decisão não difere no essencial da decisão do legislador ordinário quando produz normas legais em conformidade com a constituição. Ambos criam direito. A diferença é mais quantitativa do que qualitativa.

«A interpretação feita pelo órgão aplicador do direito é sempre autêntica. Ela cria direito.» (KELSEN, 1984, 470)

As normas legais sobre integração de lacunas não são mais do que um jogo, uma vez que o direito vigente é sempre aplicável.

«Esta teoria [teoria das lacunas] é errónea pois funda-se na ignorância do facto de que, quando a ordem jurídica não estatui qualquer dever de um indivíduo de realizar determinada conduta, permite esta conduta. A aplicação da ordem jurídica vigente não é, no caso em que a teoria tradicional admite a existência de uma lacuna, logicamente impossível. $\mathrm{Na}$ verdade, não é possível, neste caso, a aplicação de uma norma jurídica singular. Mas é possível a aplicação da ordem jurídica - e isso também é aplicação do direito.» (KELSEN, 1984, pp.338 e 339)

A lacuna resulta do facto de o aplicador entender que a ausência de uma norma jurídica é indesejável do ponto de vista da política jurídica, apesar de a aplicação do direito ser logicamente possível. Um juízo de valor ético-político subjetivo é apresentado como impossibilidade lógica. Através das normas sobre integração de lacunas, o legislador constrói a ficção de acordo com a qual a ordem jurídica vigente, em certos casos, não pode ser aplicada, não por uma razão ético-política subjetiva, mas por uma razão lógica objetiva (p.341). 
«Se ele formulasse esta atribuição de competência de uma maneira teoricamente acertada, isto é, sem qualquer ficção, deveria preceituar: quando a aplicação da ordem jurídica vigente é, segundo a conceção éticopolítica do tribunal, insatisfatória no caso sub judice, o tribunal pode decidir o caso segundo a sua livre apreciação.» (KELSEN, 1984, pp.340 e 341) «(...) parece correta a sua posição segundo a qual o direito não está plasmado na lei, de maneira a poder ser dela extraído através de procedimentos lógicoformais. Na maior parte dos casos, a lei deixa ao investigador do direito um espaço a ser preenchido mediante um ato constitutivo, de criação de direito. Segundo Kelsen, este ato é política jurídica. A ciência apenas pode estabelecer as diversas possibilidades de decisão, o quadro decisório, e só isto é designado por Kelsen como interpretação (cfr. Dworkin: o direito como prática interpretativa).» (KAUFMANN, 2009, p.182)

Se o legislador falasse com clareza e sinceridade, diria que a conceção ético-política do juiz toma o lugar da sua conceção éticopolítica quando a solução providenciada pelo ordenamento jurídico é considerada insatisfatória pelo próprio juiz. Finge uma abdicação magnânima para não admitir que essa faculdade sempre pertenceu aos juízes. Finge que o juiz pode fazer de legislador apenas quando se apresenta uma lacuna.

\section{Reformismo humanitarista e condenação do arbítrio judiciário}

«A história do direito penal oferece um verdadeiro contraste entre duas tendências opostas: a de conceder ao juiz um poder arbitrário para proporcionar a pena à culpabilidade individual do delinquente e a que consiste em não lhe conceder nenhum arbítrio. Daqui dois sistemas de todo o ponto antagónicos acerca da aplicação da pena: o da arbitrariedade e o da inflexibilidade. No primeiro sistema dá-se a omnipotência do juiz; no segundo a omnipotência da lei.» (NAVARRO DE PAIVA, s.d., p.218)

a. O arbítrio judiciário constitui, de forma inquestionável, um dos tópicos mais repetidos na literatura do reformismo humanitarista, adquirindo um sentido profundamente pejorativo. Equivale a despotismo, abuso, vontade irracional e, por consequência, injustiça. 
Beccaria opõe a lei cega e imparcial à perigosa e arbitrária prudência dos juízes (BECCARIA, 1998, p.143). Nas Instruçôes ou Nakaz (1767), de Catarina II (1729-1796) da Rússia, a condenação do arbítrio e da decisão fundada na equidade é correlativa da consagração da legalidade na fixação das penas (CATARINA II, 1769, p.63). Segundo Lardizabal y Uribe (1744-1820), considerado o Beccaria espanhol, o principal perigo do poder arbitrário é a insegurança dos cidadãos. Se se deixasse ao arbítrio dos juízes a imposição, a derrogação e a modificação das penas, a sua sorte seria sempre incerta. A vida, a honra e os bens estariam nas mãos do capricho, da malícia e da ignorância de um só homem (LADIZABAL Y URIBE, 1782, pp.70 e 71). A legalidade das punições oferece, em contrapartida, segurança.

O arbítrio era ainda olhado como um efeito indesejável dos defeitos ou das imperfeições da legislação. Se as leis eram obscuras ou se haviam caído em desuso, incorria-se no inevitável inconveniente do arbítrio. Daí a necessidade da reforma das leis. A fé que o pensamento setecentista deposita na lei é proporcional ao descrédito a que vota o arbítrio judiciário. Em reação ao sistema arbitrário, o código francês de 1791 acabaria por consagrar um sistema de penas fixas e inalteráveis, descrevendo assim o fecho de uma evolução que termina na omnipotência da lei (CHARLES, 1976, p.82).

Não faltam as posições mitigadas. Apresentando o arbítrio uma amplitude muito variada, Antoine-Joseph Thorillon (1742-séc.XIX) manifesta-se disposto a aceitar como menos perigoso o arbítrio que permitisse ao juiz decidir o quantum das penas - por exemplo, a sua duração - mas não a sua natureza ou qualidade (THORILLON, 1788, II, p.418).

Bentham (1748-1832) condena a liberdade ilimitada dos juízes, mesmo quando actuava no sentido de diminuir a pena. Alega duas razões. Em primeiro lugar, considera que o arbítrio embaraça o seu 
ministério, na medida em que estarão sempre entalados entre o medo de serem demasiadamente indulgentes, ou rigorosos demais (BENTHAM, 1822, p.71). Em segundo lugar, entende que se tornam menos escrupulosos na averiguação da verdade. Afasta no entanto a solução oposta da lei inflexível e defende em contrapartida uma certa liberdade ou poder discricional (p.72) que permitisse adequar a pena legal às circunstâncias imprevistas ou particulares, tanto da parte do crime, como da pessoa do réu. Nesta perspetiva, a liberdade do magistrado restringe-se a duas situações. O juiz pode diminuir - mas não agravar - a pena, nos casos que fazem presumir que um indivíduo é menos perigoso ou menos responsável do que outro. Tem ainda a faculdade de mudar a natureza da pena, ou porque o castigo que está designado na lei se não pode aplicar, ou porque seria menos conveniente. Neste caso, Bentham estabelece duas condições. Por um lado, quando a pena for diferente da que está expressa na lei, o juiz deve deixar a escolha ao réu. Por outro lado, todas as vezes que reduzir a pena abaixo do minimum fixado pela lei, deve ser obrigado a declarar $o$ motivo. Em relação às penas corporais simplesmente aflitivas, constatando que eram muito desiguais atendendo às diferentes circunstâncias que concorriam nos réus - sexo, idade, estado de saúde - admite a sua adequação pelo juiz (p.79). Também quanto à pena de prisão, a forma desigual como incidia sobre homens ricos ou miseráveis, saudáveis ou doentes, leva Bentham a advogar alguma liberdade do juiz para a comutar (p.105). Finalmente, admite que a aplicação da pena de trabalhos forçados deveria ser feita, segundo as circunstâncias individuais (p.148).

b. O odioso que o arbítrio judiciário recebeu na literatura setecentista apresenta duas causas: a específica conformação da lei penal antiga e o sistema de provas então vigente. Com efeito, a 
arbitrariedade resulta em grande parte da indeterminação e da inflexibilidade dos textos. Todos estes aspetos são retratados como imperfeições ou defeitos. A indeterminação legal é geralmente assinalada para a punição. Com frequência, o legislador conforma-se com penas arbitrárias. Manda aplicar punições corporais que não identifica. Açoites não quantificados. Manda morrer, sem dizer como (morra por ello). Manda cortar a mão, sem dizer qual. Os exemplos poderiam multiplicar-se... Mas essa indeterminação também se regista ao nível da incriminação. A começar pelo domínio tão sensível dos crimes políticos. Pereira e Sousa (1756-1819), citando Montesquieu e lembrando a lição da história, ensina que é da maior importância definir bem o crime de alta traição, o mais funesto ao Estado, porque a obscuridade basta para fazer degenerar um governo legal num poder arbitrário (PEREIRA E SOUSA, 1803, p.35).

A esta característica junta-se a inflexibilidade dos enunciados legais. Os delitos são geralmente definidos através de uma descrição prolixa e circunstanciada. Na ausência de um "direito penal geral", com assento legislativo, a previsão das penas, se bem que apresente variações de acordo com a condição social do agente, é insuficiente para resolver múltiplos problemas. Finalmente, a antiguidade dos textos redundava em inevitáveis desajustamentos face à época em que vigoravam.

O apreço setecentista pelo progresso não parece valorizar a intemporalidade de fórmulas que a tradição transportara, mas antes disposto a avaliar criticamente cada palavra e a apontar com severidade os anacronismos. A ciência da legislação reclama a reforma das leis penais. Reclama leis certas e determinadas.

A crítica do arbítrio judiciário encontra-se também em directa conexão com as mutações verificadas no sistema de provas. Apesar de os juízes do antigo regime gozarem de um amplo poder na escolha das 
penas, encontravam-se limitados pelo sistema de provas legais (GILISSEN, 1965, p.760), em rigor uma construção puramente doutrinal adoptada pelos tribunais (CARBASSE, 1990, p.220). Na expressão de Adhémar Esmein (1848-1913), o juiz era como um teclado que respondia inevitavelmente quando certas teclas eram tocadas (1882, p.260). Julgava secundum allegata et probata, ainda que a consciência lhe ditasse outra coisa e ele soubesse ser a verdade em contrário do que no feito era provado, como dizem as Ordenações. Porque somente ao príncipe, que não reconhecia superior, na fórmula tradicional do poder soberano, era permitido julgar segundo a sua consciência (O.F. L.III, T.66, pr.). No seu rigor inicial, apenas a prova plena (probatio plena) podia fundar uma condenação, mas o sistema acaba por produzir uma curiosa aritmética das provas e, se bem que a prova parcial - meia-prova, quarto de prova... - não conduzisse a uma pena ordinária ou total, abre-se a porta a uma condenação extraordinária. A aplicação de penas arbitrárias ou extraordinárias resultava, portanto, em parte da punição das situações de semiculpabilidade ou de culpabilidade duvidosa (ALONSO, 1989, p.218). De acordo com a Leopoldina (1786), a reforma penal do GrãoDuque Leopoldo da Toscânia (1747-1792), a falta de prova plena ou perfeita não obstava a que o juiz punisse com pena extraordinária, existindo indícios suficientes (§CX). Michel Foucault (1926-1984) conferiu uma especial dramaticidade a esta face sombria do arbítrio: a pena era proporcional à quantidade de prova reunida.

«Ou seja, não bastava dizer: é necessária uma prova plena, inteira e completa, para cominar uma pena. O direito clássico dizia: se a soma não atinge esse grau mínimo de provas a partir do qual se pode aplicar a pena plena e inteira, se a soma fica de certo modo em suspenso, se temos simplesmente três quartos de prova e não uma prova plena, isso não quer dizer que não era necessário punir. A três quartos de prova, três quartos de 
punição; a meia prova, meia pena. Dito de outro modo, não se era suspeito impunemente.» (FOUCAULT, 1999, p.8)

$\mathrm{O}$ arbítrio judiciário constituía a contrapartida do sistema de provas. No século XVIII, ao mesmo tempo que este sistema estava a ser contornado, o reformismo desenvolveu uma dura crítica ao arbítrio judiciário e o velho processo penal foi severamente atacado (FOUCAULT, 1975, p.115). Produz-se então uma movimentação que se dirige à exigência de legalidade. Antes, centrada na prova, assenta agora no domínio das penas (CARBASSE, 1990, p.220).

\section{Lei e arbítrio no antigo regime: uma diarquia de sucesso}

«Os juristas do Antigo Regime repetem à saciedade que em França todas as penas são arbitrárias. Tomada à letra, a expressão poderia fazer crer que os juízes eram livres de inventar as penas e mesmo de punir segundo a sua fantasia todo o ato que, por infelicidade, lhe desagradava. (...) No sentido comum em que se entende esta frase, antes de se tornar no século XVIII uma expressão-chave do discurso polémico, o arbítrio judiciário era uma coisa completamente diferente» (LEBIGRE, 1995, pp.214 e 215)

a. Antes do tratamento violento e crítico que lhe foi dirigido pelo reformismo, o arbítrio não era apreciado negativamente e, apesar disso, tolerado. Ao invés, configurava-se como um dos pilares da justiça penal, atuando como fator de dinamismo ou instrumento de atualização do ordenamento jurídico do antigo regime. Dotando-o de plasticidade, permitia a sua adaptação às circunstâncias sociopolíticas de cada momento histórico. Numa primeira e longa fase, constitui um dos pilares da construção científica do direito penal e, por fim, está já ao serviço da sua humanização ou da conformação das velhas regras aos ventos do humanitarismo. 
O arbitrium iudicis apresentava-se como o resultado de uma circunstância histórica em que, por um lado, o direito estabelecia penas absolutas e, por outro, a doutrina e a ética cristã exigiam que as penas correspondessem à culpabilidade real do agente. Esta contradição pelo menos aparente foi resolvida pela concessão aos juízes da faculdade de modificar as penas em casos extraordinários.

Bernard Schnapper (1927-2008) traça uma evolução de seis séculos que se inicia com o sistema medieval de penas legais fixas, passa pelo crescimento do arbítrio, que atinge o apogeu entre meados do século XIV e o século XVII, e vê desenhar o seu desfecho com as novas ideias políticas de que decorria o princípio da legalidade, a asfixia do poder arbitrário e um novo sistema de provas (pp.50-70). O naufrágio do sistema medieval das penas fixas cedeu lugar ao princípio das penas arbitrárias. Numa primeira fase, os doutores equilibraram o poder discricionário dos juízes com o sistema de provas. E rejeitaram a possibilidade de incriminar sem norma de direito positivo. Numa segunda fase, através de uma terrível evolução, o poder dos juízes produziu, contudo, progressos inquietantes (p.72).

A teoria do direito (LAINGUI, 1989, pp.161-194) que permitia aos juízes modificarem a pena legal, construída pelos glosadores, resulta da ideia de que a pena comum ou estatutária - a pena ordinária - era estabelecida somente para o caso "normal" previsto pelo legislador. A "normalidade" traduzia-se na exata verificação da factualidade descrita na lei.

Esta conceção do arbítrio era apoiada em vários fundamentos. O poder arbitrário dos juízes encontrava-se juridicamente regulado (CARBASSE, 1990, p.124 e p.202). E correspondia ao exercício mais nobre da função do juiz. Os glosadores construíram a partir do direito romano uma teoria sobre o arbítrio das penas (CARBASSE, 1990, pp.207-210; LEBIGRE, 1995, p.216). Desta forma, considerou-se que o 
juiz se podia afastar da pena ordinária havendo causa, ou seja, quando se verificassem especiais circunstâncias que modificavam o caso "normal", "atenuando-o" ou "agravando-o". Dentro de determinados limites, o juiz podia atuar além e aquém das penas estabelecidas. Impunha então uma pena extraordinária. Mas a própria matriz romana do poder arbitrário, o texto de Ulpiano conhecido como lei Hodie (D. $48,19,13)$, que serviu de base a toda a teoria medieval das penas arbitrárias, desenhava a fronteira dessa modulação judiciária: a moderação ou razoabilidade.

Começou, pois, a definir-se a ideia de que o juiz, embora vinculado às penas legais, e dentro de certos limites, podia temperar ou agravar essas penas, desde que existisse uma causa. Alfonso de Castro (1495-1558), no De potestate legis poenalis (1550), faz uso desta terminologia: o juiz, não obstante a sua subordinação à lei, pode - com justa causa - moderar a severidade da lei penal. Foram aparecendo então listas ou enunciados de causas de mitigação e de agravamento das penas. Pierre de Belleperche (1230?-1308) fez uma primeira. A obra de Tiraqueau - De poenis temperandis - constitui o exemplo mais paradigmático deste método. Verifica-se aliás neste domínio um assinalado alinhamento metodológico ao longo de todo o antigo regime.

O direito penal que chega ao século XVIII é largamente tributário da doutrina erudita e do direito romano. Esse direito penal comum transportava o princípio das penas arbitrárias. O ius podia ser corrigido pela perfeita justiça da aequitas (HESPANHA, 1990, p.400; BARBAS HOMEM, 2003, pp.282-283 e pp.311-312).

Tomás António Gonzaga (1744-1810), quando escreve sobre a interpretação das leis no seu Tratado de Direito Natural, dedicado ao Marquês de Pombal, dá nota de que a equidade tem grande exercício na praxe. 
«A equidade é uma espécie de interpretação restritiva, que temos necessidade de usar todas as vezes que, de executarmos o rigor da lei, se seguir alguma coisa injusta. Esta interpretação tem um grande exercício na praxe, pois sendo a lei uma regra única, é certo que ela não se pode aplicar a todos os casos que ocorrerem, pois que estes são muitos e diversos. Ponhamos um exemplo: Manda o rei que todo o que matar que morra; ora esta lei não deve entender-se tão geralmente, que digamos que ela abraça não só ao que mata com um ânimo deliberado de a quebrar, mas ainda ao que a quebra em caso repentino, quando a mágoa da injúria nem lhe dá lugar a pensar em semelhante lei. Logo, devemos interpretar esta lei restringindo a sua disposição, todas as vezes que o homicídio não for com ânimo deliberado, e assim lhe iremos diminuindo a pena à proporção da maldade que o delinquente mostrou na execução do insulto.» (GONZAGA, 1957, p.147)

As listas de causas foram aumentando, embora não sejam por natureza exaustivas e careçam de sistematicidade. Integram questões como a idade - a pouca idade ou a idade avançada - o carácter intencional ou não intencional do delito, o interesse do Estado, os laços familiares entre o delinquente e a vítima, a reincidência... Algumas dessas causas dizem respeito a típicos problemas de responsabilidade penal: imputabilidade, culpabilidade e causas de justificação. Mas encontramos causas de diferente natureza, como o escândalo que o crime provocava ou os serviços notáveis que o delinquente havia prestado ou poderia prestar ao Estado.

b. O direito do antigo regime reúne duas declarações aparentemente contraditórias, muito frequentes nos textos legais e doutrinários: o juiz não deve afastar a pena da lei e, não podendo o legislador compreender tudo nas leis, deixa-lhe o arbítrio de deliberar como lhe parece justo. 
«Atenua-se a pena, olhando à idade, sexo, dignidade, e sobretudo ao grau de dolo ou culpa, e a outras circunstâncias que parecem diminuir a atrocidade do delito e devem ser previamente consideradas. Porém, isto respeita aos Imperantes, a quem pertence determinar certas penas mais brandas ou mais pesadas, consoante a qualidade do delito, pois os juízes não podem diminuir nem aumentar as penas legais. A estes somente foi permitido que na interpretação das leis antes adoçassem as penas.» (MELLO FREIRE, 1966, p.77)

«E assim deve o Julgador advertir, que os Legisladores não podendo compreender tudo nas Leis, por serem muitos os casos ocorrentes, lhes deixarão a seu arbítrio o deliberarem como lhes parecer justiça.» (VANGUERVE CABRAL, 1730, p.313)

No extremo oposto à afirmação de que o juiz se encontra subordinado à lei, encontra-se o adágio francês segundo o qual todas as penas são arbitrárias. A este procedimento não é naturalmente alheia a metodologia casuística da teologia moral e do direito canónico. $\mathrm{O}$ apuramento da responsabilidade penal implica um mecanismo idêntico ao dos confessores (CARBASSE, 1990, pp.210 e 211; ORTEGO GIL, 2000, pp.319-322 e 348). Ambos têm que pesar o ato culposo, através dos seus elementos externos (factuais) e internos (disposições psicológicas). Não por acaso, S. Tomás de Aquino (1225-1274) aconselha aos teólogos as famosas questões que definem as circunstâncias dos atos humanos, que atribui a Cícero (106 a.C.-43 a.C.) e que frequentemente são também imputadas a Quintiliano (séc. I): quis, quid, ubi, quibus auxiliis, cur, quomodo, quando (Suma Teológica, P.1-2, Q.7, A.4).

Arbitrar significava realizar uma avaliação de tudo aquilo que era então reconduzido às circunstâncias da infração: a gravidade do delito e a culpabilidade precisa do seu autor. O juiz devia, portanto, 
examinar todos os elementos constitutivos do delito: os factos; as circunstâncias objetivas relativas ao tempo e ao lugar; a personalidade do delinquente (idade, sexo, condição, relação com a vítima, discernimento); causas de exclusão, atenuação ou agravamento da pena... Em suma, arbitrar implicava apreciar todos os parâmetros da responsabilidade do delinquente. $\mathrm{O}$ arbítrio dos juízes foi, a par da doutrina, um dos berços do direito penal do antigo regime.

A teoria das circunstâncias do crime envolve um pelo menos aparente paradoxo - ordenar o arbitrário. Ao mesmo tempo que deixa a decisão de punir aberta à possibilidade infinita de circunstâncias, fecha-as num catálogo mais ou menos sistemático (PORRET, 1995, p.18).

Como defendeu Tomás y Valiente (1932-1996), nomeadamente a propósito da tortura, em virtude da proximidade face ao poder real, quanto mais se sobe na hierarquia judiciária maior é o campo de ação do arbítrio ou, mais exatamente, maior é (potencialmente) o afastamento da lei (TOMÁS Y VALIENTE, 1971, p.483), assim como a benevolência penal (ORTEGO GIL, 2000, p.293). A inexistência de separação de poderes permite que a decisão judicial seja também um ato de governo ou a execução eficaz das necessidades da política penal. A aplicação fiel da lei revela-se deste modo inversamente proporcional à proximidade do monarca. Porém, admite-se hoje que o poder dos juízes do antigo regime era infinitamente mais diminuto que o dos juízes modernos (LAINGUI, 2000, p.107).

Em Castela ou em França, a ampliação do arbítrio e até os seus abusos terão sido favorecidos pelo facto de os juízes não estarem obrigados à fundamentação das sentenças. $O$ direito comum não impelia aliás a solução diversa.

Contudo, de acordo com a Leopoldina, a condenação a pena arbitrária devia ser fundamentada (§CXVI). Proporcionando a 
formação de uma jurisprudência uniforme, cada tribunal deveria conservar um registo de todas as sentenças arbitrárias, organizado de acordo com o crime, por ordem alfabética. Aí devia mencionar-se o conjunto das circunstâncias que agravavam ou diminuíam os delitos (§ CXVII).

Portugal havia já adotado historicamente a regra oposta (OM L.III, T.50, §6; e OF L.III, T.66, §7), precaução da legislação nacional que António Ribeiro dos Santos (1745-1818) considerava saudável, uma vez que prendia as mãos aos julgadores (RIBEIRO DOS SANTOS, 1814, p.132).

«E para as partes saberem se lhes convém apelar, ou agravar das sentenças definitivas, ou vir com embargos a elas, e os Juízes da mor alçada entenderem melhor os fundamentos, por que os Juízes inferiores se movem a condenar, ou absolver, mandamos que todos os nossos Desembargadores, e quaisquer outros Julgadores, ora sejam Letrados, ora o não sejam, declarem especificamente em suas sentenças definitivas, assim na primeira instância, como no caso da apelação, ou agravo, ou revista, as causas, em que se fundaram a condenar, ou absolver, ou a confirmar, ou revogar.» (OF L.III, T.66, §7)

c. Os juízes encontravam-se limitados na escolha da pena a arbitrar por um maximum e por um minimum. Assim como não podiam mitigar ou remitir a pena legal sem causa, defrontavam-se - de acordo com o que parece ser a doutrina dominante - com outro limite fundamental, quanto à possibilidade simétrica de proceder ao agravamento: a inadmissibilidade do arbítrio usque ad mortem (LAINGUI, 1970, p.18; SCHNAPPER, 1974, pp.37, 47 e 57; HESPANHA, 1990, p. 400; em sentido diverso, ORTEGO GIL, 2004, pp. 228 e 229). 
Segundo Voltaire (1694-1778), adverso à pena capital, a questão funesta e delicada sobre a possibilidade de os juízes condenarem à morte, quando as leis não o determinavam expressamente, havia sido agitada durante longo tempo (VOLTAIRE, 1767, p.30).

Entre nós, o ensinamento de Mello Freire e de Pereira e Sousa não deixa margem a quaisquer dúvidas: a pena arbitrária não podia estender-se até à morte, sem especial permissão da lei (MELLO FREIRE, 1966, p.72). Seria dar a um cidadão sobre outro o direito da vida e da morte, o que é absurdo (PEREIRA E SOUSA, 1803, nota 33 ao 21, p.22).

\section{De Poenis Temperandis}

«O juiz não pode, inconsideradamente e sem causa, diminuir ou aumentar as penas determinadas pela lei (...)» (TIRAQUEAU, 1986, p.30)

O primeiro grande tratado de responsabilidade penal, de Tiraqueau ou Tiraquellus (1488-1558), significativamente intitulado De poenis temperandis (1559), ao tratar das causas de exclusão e de atenuação da pena, recebe em boa parte o contributo dos pósglosadores, que haviam construído a teoria do direito que atribuía ao juiz a faculdade de modificar a pena legal ordinária.

Os historiadores do século XIX fizeram abater sobre Tiraqueau a acusação de que havia aberto as portas ao arbítrio no âmbito da determinação das punições. Entretanto, o arbítrio judicial havia sofrido uma intensa crítica e um tal comentário tinha, portanto, o significado de uma apreciação profundamente negativa.

Esta acusação padece, contudo, de vários erros (SCHAFFSTEIN, 1957, pp.62 e 63), que se nos afiguram de perspetiva. Em primeiro lugar, constata-se uma "desfocagem" do problema em virtude do ponto de vista histórico. A análise que a proporciona usa a lente deformadora 
do futuro, partindo da estreita vinculação político-jurídica do juiz em direção ao passado. Em consequência, inverte-se o sentido do contributo de Tiraqueau. Na verdade, não confere maior amplitude ao arbítrio judiciário. Em boa parte, não é sequer original face ao trabalho dos pós-glosadores. $\mathrm{E}$ decididamente não procede à ampliação do poder dos juízes. Verifica-se, portanto, também um erro de perspetiva metodológica. Ao reunir e sistematizar as causas de atenuação e de exclusão da pena, Tiraqueau não faz mais do que limitar as faculdades arbitrárias do juiz aos seus próprios enunciados. O sentido do seu catálogo é precisamente o de definir as fronteiras do arbítrio judiciário.

Constatam-se deste modo restrições ao poder dos juízes face ao passado. Por exemplo, a figura jurídica da actio libera in causa limita os efeitos do sono e da embriaguez quanto à possibilidade de se atenuarem as punições ou mesmo de eximir o agente. Quanto à ignorantia iuris, rompe-se o princípio que afastava a pena, através de onze exceções rigorosamente circunscritas.

Em Tiraqueau encontramos mesmo um esboço do princípio da legalidade quando se afirma a vinculação do juiz ao direito estabelecido: quando uma pena precisa é determinada pela lei ou pelo costume, o juiz não a pode remitir, diminuir, aumentar ou modificar de acordo com o seu arbíbrio (TIRAQUEAU, 1986, p.27). Seria absurdo que o inferior pudesse afastar ou modificar a lei do superior. Parafraseando S. Tomás de Aquino (TIRAQUEAU, 1986, p.28), considera que o criminoso deve receber a pena que está determinada no direito divino e no direito humano, uma vez que não cabe ao juiz fazer misericórdia. O princípio é estabelecido tanto no interesse daquele que acusa como no interesse do Estado (SCHAFFSTEIN, 1957, p.63). Segundo o Príncipe dos Teólogos, o juiz que indevidamente perdoava a pena prejudicava a sociedade, a quem importava o castigo 
das más acções para evitar os delitos, e a vítima da injúria (Suma Teológica, P.2-2, Q.67, A.4, R.3).

Todo o Prefácio debate este problema, que estava na base de uma prática frequente e quotidiana (TIRAQUEAU, 1986, p.37) dos juízes, montando os alicerces da sua obra. Não se esquece aliás das consequências penais do capricho judiciário. Simplesmente, de acordo com a tradição, a legalidade não significa exclusividade da lei mas uma regra que cede perante a verificação de uma causa ou motivo que justifica o poder arbitrário.

Apesar de representar um paradigma na teoria do poder arbitrário, Tiraqueau não foi alheio aos perigos dos abusos que esta era susceptível de envolver. Assim, entende que se o juiz exclui, atenua ou agrava de forma leviana - ou sem causa - a pena legal ou consuetudinária, torna-se conscius criminis e deve ser castigado com a punição estabelecida para o delito em causa. Por exemplo, tamquam committens crimen laesae maiestatis. Se impõe a pena de morte sem poder legal, é ele próprio homicida e como tal deve ser castigado. Dando causa ao fracasso da justiça, responde talionicamente (TIRAQUEAU, 1986, pp.28-30).

\section{Penas ordinárias e penas extraordinárias}

«Ordena, e Manda o Mesmo Senhor, que V. Ex. em Seu Real Nome advirta os Ministros, que reviram todo o dito Feito, que Sua Majestade se deu por muito mal servido do modo com que procederam neste caso, e que usando por esta só vez da Sua Real benignidade, e clemência se serve de perdoar-lhes o castigo, que mereciam por facto desta injustiça, e lhes manda que se abstenham totalmente de semelhantes procedimentos, tendo entendido que nenhuma outra cousa são nos lugares, que Ele confere, mais que uns meros executores da Lei para se não afastarem das suas determinações, e opiniões mais seguras dos Doutores, obrando sempre com os olhos em Deus, e no serviço de Sua Majestade, quietação e sossego dos seus fiéis Vassalos.» (Aviso de 10 de abril de 1751, que estranha à Casa da 
Suplicação haver confirmado uma sentença notoriamente injusta; DELGADO, 1842, p.98)

a. A distinção legal e doutrinária entre penas ordinárias e penas extraordinárias reflete o âmago do direito penal do antigo regime enquanto sábia e pacífica articulação entre legalidade e arbítrio. A lei estabelecia a punição ordinária, aplicada quando o delito era praticado de acordo com a descrição circunstanciada nela contida (pena legal ou legítima). Verificando-se, contudo, outras circunstâncias atendíveis, o juiz podia impor uma pena diferente (extraordinária ou arbitrária) (TOMÁS Y VALIENTE, 1992, pp.332 e 333; GARRAUD, 1912, p.39).

As definições apresentadas pelos penalistas, nas suas similitudes e nas suas específicas colorações, constituem um valioso ponto de partida para o estudo dos mecanismos de determinação judicial da pena.

Muyart de Vouglans (1713-1791) identifica como centro do critério classificatório das penas o próprio juiz. Enquanto a pena ordinária devia ser pronunciada tal como se encontrava fixada na lei, a pena arbitrária era ditada no exercício da liberdade, que a própria lei conferia ao juiz, de julgar de acordo com as circunstâncias (VOUGLANS, 1781, p.47).

O Dicionário Jurídico de Pereira e Sousa opõe o adjetivo arbitrário à lei, identificando-o com a arbitrariedade judicial e esta com a aplicação das penas. Nas suas palavras, arbitrário é o que fica no livre arbítrio ou vontade de alguém, e que depende dela, e não é determinado por lei. Assim, diziam-se penas arbitrárias as que se deixavam à descrição do magistrado (I, voz arbitrário). O seu tratado prende contudo o arbítrio a uma concessão legal. As penas legítimas ou ordinárias são as que estão impostas nas leis; e as penas arbitrárias ou extraordinárias, as que a lei deixa ao arbítrio do magistrado 
(PEREIRA E SOUSA, 1803, nota 33 ao §21, p.22). Revelando maior proximidade com o texto de Vouglans, na medida em que o poder arbitrário dos juízes é conferido pela lei, apresenta um conceito de pena arbitrária que corresponde a uma arbitrariedade legal ou, de certo modo, a uma legalidade indireta. Numa perspetiva política, através do exercício de um poder arbitrário delegado é ainda o poder real que se afirma (LEBIGRE, 1995, pp. 216 e 217).

O enunciado de Daniel Jousse (1704-1781) importa para a caracterização do poder arbitrário dos juízes do antigo regime uma ideia que se aparta completamente da avaliação resultante do discurso iluminado de setecentos, onde se precipitam os maiores males: desproporção das punições, incerteza do direito e, em consequência, insegurança do cidadão. No seu entendimento, o arbítrio judiciário não constituía uma causa de exacerbação das penas. Enquanto as penas ordinárias eram determinadas pela lei ou pelo uso para determinados crimes, as penas extraordinárias constituem outras penas menores, aplicadas aos mesmos crimes por motivos de temperamento ou de equidade, resultantes das circunstâncias que os tornavam mais desculpáveis (plus excusables) ou da falta de provas suficientes (JOUSSE, 1771, I, p.38; e II, p.591). Ainda que benevolamente, atuaria o juiz sem qualquer limite? Segundo Jousse, enquanto as penas legais eram estabelecidas pelas leis, as penas arbitrárias dependiam da prudência do juiz (JOUSSE, 1771, I, pp.37 e 38). Cuida então de circunscrever o âmbito dessa prudência no conceito de pena arbitrária, acrescentando que eram infligidas em proporção com a gravidade do crime e segundo das circunstâncias que o podiam tornar mais ou menos grave. As fronteiras da prudência judicial adquirem maior precisão quando se definem as regras que o juiz deve seguir para impor as penas. 
O apelo à virtude dos juízes não é também alheio à lei, que manda julgar segundo alvidro de bom Juiz (OA L.V, T.60, §3).

Em suma, as fronteiras do poder arbitrário existiam, tinham uma natureza jurídica e resultavam sobretudo do ancestral labor da doutrina.

b. Nas palavras de Eduardo Correia (1915-1991), um quadro geral do sistema punitivo das Ordenações Afonsinas só se alcança quando, ao lado das penas legítimas ordinárias... se considere que elas previam uma série de 'penas arbitrárias'(CORREIA, 1977, p.85). Nas Ordenações Manuelinas, são cominadas em largo número, sendo por vezes a condenação até à morte, inclusive, aqui expressamente consentida (p.93). Nas Ordenações Filipinas, aparecem verdadeiramente prodigalizadas (p.102).

As Ordenações são depositárias de uma grande variedade de fórmulas referentes ao poder arbitrário dos juízes. O legislador faz uso da expressão medieval, cominando pena alvidrosa, a determinar pelo juiz (OA L.V, T.30, §11), pena ao alvidro do rei (OA L.V, T.45, §13), do julgador (OA L.V, T.23, §3) ou pena segundo o alvidro de bom juiz (OA L.V, T.60, §3). Mas encontramos igualmente as designações que perdurariam: pena arbitrária (OA L.V, T.29, §§1 e 3; OF L.V, T.26, pr.; e T.118, §1) e pena extraordinária (OF L.V, T.13, §3), bem como a expressão correlativa, pena ordinária (OF L.V, T.13, §6; e T.66, §1). Manda punir segundo o arbítrio do julgador (OF L.V, T.26, §1; T.48, § 3; e T.60, §8). Determina que a pena ficará em arbítrio do julgador (OF L.V, T.42; e T.51). Recorre a soluções mais prolixas e difusas, que acentuam a amplitude do poder arbitrário, condenando ao que for nossa mercê (OM L.V, T.112, §§11, 24 e 25), como for minha mercê (OA L.V, T.31, §4), qual nossa mercê for (OA L.V, T.58, §11), o que houvermos por nosso serviço (OF L.V, T.82, §4), o que houvermos por 
bem (OF L.V, T.107, §13), à mercê do Senhor Rei para lhe dar pena, qual entender (OA L.V , T.43, §4), como Nos parecer que merece (OM L.V, T.112, §3; OF L.V, T.107, §2), nos bem parecer (OF L.V, T.119, pr.) ou que merecerem (OF L.I, T.33, §5).

O legislador consente na condenação em pena que bem parecer aos juízes (OF L.V, T.26, pr.), sem deixar de, simultaneamente, desenhar os contornos mais ou menos precisos desse poder que outorga ao julgador. Manda então punir arbitrariamente, mas segundo $o$ malefício cometido (OA L.V, T.26). Segundo a qualidade do feito (OA L.V, T.32, §4). Segundo a culpa ou malícia em que for achado (OA L.V, T.52, §4). Atendendo à gravidade da conduta e à intensidade da culpa, a lei faz sobressair a índole jurídica da faculdade de impor penas arbitrárias. Com efeito, o arbítrio não atua à margem do direito. É este que o outorga e define as suas fronteiras. Prendam-nos, e façam deles direito (OA L.V, T.105, §1), declara a própria lei.

Estas expressões revelam ainda que o grau de arbitrariedade se pode configurar de forma mais ou menos ampla. Por vezes, o legislador concede um poder arbitral sem qualquer limitação expressa. Por exemplo, coloca o criminoso à mercê do dito Senhor Rey pera lhe dar pena, qual entender (OA L.V, T.43, §4). Manda que seja gravemente castigado (OF L.V, T.84, §2). Determina a condenação em pena arbitrária do juiz, qual entender que merece (OA L.V, T.29, §§1 e 3). Ou que for Nossa Mercê (OM T.112, §§11, 24 e 25). Noutros casos, porém, orienta o juiz quanto ao tipo de pena a aplicar. Ordena então que os seus corpos e haveres sejam obrigados a mim, e à minha Justiça, pera lho eu estranhar, como for minha mercê (OA L.V, T.31, §4). O arbítrio permite determinar o tipo de pena corporal e de pena patrimonial, assim como o respetivo quantum. Reduzindo a amplitude do poder arbitrário, o legislador comina degredo arbitrário, cabendo ao juiz a sua concretização, quer quanto ao local, quer quanto o tempo: 
haverá a mais pena de degredo, que houvermos por bem (OF L.V, T.47).

$\mathrm{Na}$ sua manifestação minimalista mais frequente, o poder arbitrário exprime-se através da mera quantificação das penas. Fixando o montante exato da pena pecuniária (OF L.V, T.23, pr.). E o tempo exato do degredo (OF L.V, T.108) ou da prisão (OF L.V, T.114). Os textos podem ainda impor um limite máximo ao exercício do arbítrio, constituindo o castigo legal uma combinação de confisco e degredo: até perdimento de todas as suas fazendas, e degredo para sempre para as Ilhas de Ano Bom, ou Santa Helena, qual Nos prover (OM L.V, T.112, §3). Por fim, o juiz pode simplesmente decidir a forma de execução da pena.

Entre a livre escolha e a mera quantificação da pena determinada pela lei existem campos de atuação intermédios. Nestes casos, os poderes arbitrários do juiz podiam exercer-se em relação à espécie ou à natureza da pena (CORREIA, 1977, p.85). Escolhendo entre o degredo ou a pena pecuniária. Ou determinando a pena corporal a aplicar (OA LV, T.2, §21).

A fixação da pena arbitrária decorre em certos casos da necessidade de tornar a norma punitiva exequível. Aquele que injuriasse pessoa com quem trouxesse demanda era condenado em pena crime e cível em dobro. Ora, não sendo a pena tal que pudesse ser dobrada, ficava em arbítrio do Julgador dar-lhe mais outra, segundo o caso merecer (OF L.V, T.42).

Apesar de normalmente o arbítrio atuar de forma a mitigar a pena ordinária, por isso também designada como pena total (OF L.V, T.135), a lei consagra por vezes a faculdade de condenar em maior pena (OF L.V, T.10; T.17, §3; T.84, §2). A aleivosia tornava assim a pena corporal muito mais grave e maior do que se daria em outro semelhante malefício (OF L.V, T.37, §1). O arbítrio ponderava as 
circunstâncias, agravantes ou atenuantes. Não surpreende por isso que a lei preveja igualmente a possibilidade de o juiz determinar pena menor (OF L.V, T.60, §2). Nestes casos, o legislador impõe uma direção ao julgador, qualificando a circunstância em causa: castigar aquém ou além da pena ordinária. Esta constitui então o limite máximo ou o limite mínimo da punição.

$\mathrm{O}$ arbítrio compreende em certas normas a possibilidade de se condenar até morte inclusive (OF L.V, T.7; T.60, §8; T.107, §2). Outras, ao invés, impõem expressamente como limite a pena última (OF L.V, T.26, §1). Embora com raridade, o legislador circunscreve a fronteira mínima e máxima do poder arbitrário de punir determinado crime: por exemplo, de dois anos de degredo para África até morte exclusive (OF L.V, T.65, pr.).

As Ordenações preveem também a aplicação de pena arbitrária em caso de prova incompleta; assim sucede a propósito do pecado de sodomia.

«E vista a graveza do caso, os Julgadores serão advertidos, que quando os tocamentos desonestos e torpes não forem bastantes para, conforme a esta Ordenação e Direito, se haver per eles o delito por provado, de maneira que os culpados devam haver a pena ordinária, ao menos os tais tocamentos se castiguem gravemente com degredo de galés, e outras penas, segundo o modo e perseverança do pecado.» (OF L.V, T.13, §6)

Em suma, as Ordenações utilizam puras fórmulas do poder arbitrário ou fórmulas diretivas desse poder, indicativas das regras ou dos critérios que o deveriam guiar, como a gravidade do crime e a culpa ou a malícia do agente. Os textos impõem que se puna segundo a qualidade do feito (OA L.V, T.32, §4), de suas culpas (OM L.V, T.112, $\S 3$ ) ou segundo a culpa ou malícia em que for achado (OA L.V, T.52, $\S 4)$. O critério legal de decisão da pena arbitrária corresponde de forma 
expressa em alguns preceitos à ponderação das circunstâncias: conforme a qualidade das palavras, pessoa, tempo, modo e tenção (OF L.V, T.7). Conforme a qualidade do caso e das pessoas, e circunstâncias dele (OF L.V, T.60, §8). Havendo respeito à quantidade e qualidade do furto, assim como do ladrão (OF L.V, T.60, §2). Segundo a qualidade da malícia, e a prova, que dela houver (OF L.V, T.118, §1). Segundo o modo e perseverança do pecado (OF L.V, T.13, $\S \S 3$ e 6). Mais difusamente, a lei permite punir segundo o caso for (OF L.V, T.17, §3) ou o caso merecer (OF L. V, T. 42). O excesso de legítima defesa é sancionado segundo a qualidade do excesso e o homicídio sem malícia ou vontade de matar é punido ou relevado segundo sua culpa ou inocência (OF L.V, T.35, pr.). Entre as circunstâncias mais salientes, avulta a condição do agente e da vítima. Havendo respeito às qualidades das pessoas, e culpas (OF L.V, T.48, §3). Segundo a qualidade das pessoas e da culpa (OF L.V, T.51). Havendo parecer à qualidade das pessoas e segundo a qualidade das pessoas, e como achar per nossas Ordenações e Direito, que merece pela dita culpa (OF L.V, T.50, pr. e §6). Em relação aos que abrem cartas alheias, a ordenação manda considerar a qualidade das pessoas que as enviarem, e a quem forem enviadas, e ao que nelas for conteúdo, e da pessoa que as abrir (OF L.V, T.8, §5). Os escritos difamatórios e as trovas de maldizer são punidos havendo-se respeito à qualidade das palavras e difamação, $e$ das pessoas contra quem os tais escritos ou trovas são feitas (OF L.V, T.84, §2).

A punição da lei pode apresentar um carácter compósito, em parte legal e em parte arbitrário. Referimo-nos, é claro, ao arbítrio legal ou expressamente previsto pelo legislador. Ou seja, a pena legal pode ser parcialmente arbitrária (OF L.V, T.10; T.13, §3; T.17, §3; T.107, §§2 e 13; T.118, §1). Então, a par de penas determinadas, o legislador declara: e mais ficará em arbítrio do julgador. Ou ainda: lhe 
será mais dada qualquer outra pena. Mais a pena arbitrária que lhe bem e direito parecer. E outras penas extraordinárias.

Os textos legais identificam também os titulares do poder arbitrário ou, mais rigorosamente, as entidades que diretamente o podem exercer: o rei (OA L.V, T.2, §21; T.31, §4; T.43, §4; T.45, §13; OM L.V, T.112, $\S \S 3,11,24$ e 25) e os juízes ou julgadores (OA L.V, T.26; T.29, §1; T.30, §11; T.60, §3; OF L.V, T.10; T.26, pr. e §1; T.42; T.48, §3; T.51; T.60 §§2 e 8; T.65, pr.). Considerando que solus princeps poterit magistratus creare (NEGREIROS, 1754, pp. 2 e 3) e que os juízes exercem um mero poder delegado dos monarcas, o arbítrio judiciário não é mais do que uma faceta do poder real.

c. No século que antecede a codificação, os textos das leis revelam, na perspetiva de um poder político contemporâneo de intensas críticas doutrinárias, quer o entendimento quer o domínio de atuação das penas arbitrárias. Uma tal análise tem lugar no território da legalidade, do arbítrio tolerado e regulado pelo legislador, mas permite entrever a relação com o puro arbítrio judiciário.

$\mathrm{Na}$ terminologia comum às fontes legislativas e doutrinárias, as penas legais e as penas arbitrárias ou extraordinárias convivem, sem antagonismo, como partes integrantes do direito penal do antigo regime. As penas arbitrárias não se encontram na lei, embora dos textos legais resulte um consentimento implícito.

O Regimento de 10 de outubro de 1753 opõe a pena ordinária, prevista na lei, à pena arbitrária, sentenciada pelo tribunal como lhe parecia (DELGADO, 1842, p.272). O Decreto de 18 de julho de 1758 faz aplicar irremissivelmente a pena ordinária aos presos das galés que se amotinassem porque considera insuficientes as penas extraordinárias (DELGADO, 1830, pp.629 e 630). Idêntica contraposição terminológica emerge em vários diplomas. Em suma, o 
arbítrio é reservado aos casos extraordinários. $\mathrm{E}$ as penas legais aos casos ordinários.

As fórmulas do poder arbitrário, por mais amplas que se configurem, têm assento legal. A lei manda castigar com as penas que reservo ao Meu Real Arbítrio (DELGADO, 1829, p.666); ou a arbitrio dos julgadores (DELGADO, 1830, p.18). O poder de castigar arbitrariamente identifica-se na linguagem das leis com o próprio poder real quando se ordena proceder contra os desobedientes, como rebeldes, com aquelas demonstrações de castigo, que cabem no Meu Justo e Real Poder (DELGADO, 1829, p.324). O poder de julgar incluindo o poder de julgar arbitrariamente - tem uma origem comum.

A imposição de penas arbitrárias envolve por vezes a expressa referência ao consentimento de Sua Majestade. A vénia a esta exigência encontra-se na Provisão do Inquisidor Geral de 22 de fevereiro de 1798, que prevê a sua aplicação a membros do clero pela justiça eclesiástica (DELGADO, 1847, p.142).

A dependência do arbítrio judiciário face à lei demonstra-se sobretudo através das regras do arbítrio, ou seja, através dos enunciados que definem os critérios da decisão arbitrária. O emprego de expressões difusas ou até vagas, como as que mandam castigar asperamente, severamente, com a maior severidade ou com as mais graves penas, que sugerem um carácter mais ou menos ilimitado do poder arbitrário do juiz, não obsta à indicação legislativa de critérios de decisão.

As regras do arbítrio (legal) conhecem vários graus de concretização. Num plano em que essas regras são mais sugeridas do que enunciadas, os textos referem-se à pena que o caso pede, merece ou parece digno. $\mathrm{O}$ monarca ameaça com o castigo que os delinquentes merecem (DELGADO, 1828, p.32). Segundo a exigência dos casos (DELGADO, 1829, p.337). 
As regras legais do arbítrio judiciário fazem prova de que este não atuava ilimitadamente. Densificam o seu carácter jurídico. As leis não partilham os receios de que a doutrina setecentista faz alarde. Confiam no arbítrio prudente dos juízes (DELGADO, 1830, p.695) ou no seu regulado arbítrio (DELGADO, 1829, p.129). A fronteira jurídica do poder arbitral desenha-se para além do direito positivo. Nos quadros mentais do antigo regime, o juiz, antes de servir a lei positiva, serve a lei natural, serve a justiça. A lei natural impunha aos juízes o respeito pela equidade. A sentença arbitrária devia ser equitativa e nunca a pura manifestação de uma vontade caprichosa e despótica. $\mathrm{Na}$ perspetiva da lei, não existem sinais de tensão com o arbítrio judiciário.

\section{António Ribeiro dos Santos: a proposta moderada de um arbítrio restrito e limitado}

«(...) a ninguém deve pertencer, senão à lei, estabelecer a pena para os culpados (...)» (RIBEIRO DOS SANTOS, 1844, p.187)

O entendimento do arbítrio judicial evoluiu até se aproximar de formulações muito próximas da atuação do juiz atual, como sucede no pensamento de António Ribeiro dos Santos. O seu Discurso sobre a Pena de Morte, publicado em 1814 no Jornal de Coimbra, é mais do que um texto abolicionista. Inclui, na sua quarta e última parte, uma reflexão própria e moderada sobre o poder do juiz na determinação das penas.

O canonista distingue o arbítrio absoluto do arbítrio restrito ou limitado. Num discurso não isento de tautologias, produz um longo elenco de razões pelas quais o arbítrio absoluto deveria ser postergado em benefício da lei (RIBEIRO DOS SANTOS, 1814, pp.124 e 125). No mesmo sentido pronuncia-se aliás enquanto censor régio, nas Notas ao Plano do Novo Código que havia sido apresentado por Mello Freire, 
onde enumera três argumentos, identificados com os sentimentos dos criminalistas modernos: a pena deve ser fixada pela lei; a pena deve ser manifesta a todos; do arbítrio podem resultar infinitos males, maiores do que aqueles que podem nascer da sua proibição (RIBEIRO DOS SANTOS, 1844, p.187).

O arbítrio implica conferir ao juiz uma parte do poder legislativo e, portanto, infringir a separação de poderes. Ocasiona a variedade de juízos em casos idênticos. Perturba a segurança do cidadão. Este acomoda-se mais facilmente à lei do que à decisão do juiz. Na lei reconhece uma superioridade natural e no juiz vê um homem como ele. A lei é, ao invés, fixa, meditada, sábia e incorrupta.

O rumo está deste modo no essencial definido: fixar as penas na lei e limitar o arbítrio. Mas é ainda necessário compatibilizar esta orientação com as tarefas do juiz. Ora, este tem de realizar duas operações. A primeira, a que não pode fugir, consiste em conhecer toda a natureza e circunstâncias do crime. Através da segunda, deve determinar a pena correspondente. Mesmo o juiz mais prudente $e$ sábio não consegue afastar o risco de se ver em muita flutuação $e$ incerteza, de precipitar o seu juízo, de impor ao delito uma pena diferente daquela que lhe imporia ou deveria impor o legislador, uma pena muito maior ou menor do que pediam as circunstâncias do crime. A lei deve portanto fixar a pena de cada género ou espécie de delito.

«Não sendo pois conveniente o arbítrio da pena geral em nenhum caso crime, é de necessidade que a lei determinadamente a imponha, fixando demarcadamente a cada género ou espécie de delito a pena correspondente.» (RIBEIRO DOS SANTOS, 1814, p.126) 
Ribeiro dos Santos define, em abstrato, três modelos que articulam a conformação da lei e a margem de atuação do magistrado. O primeiro corresponde à descrição circunstanciada, prolixa, confusa e, simultaneamente, lacunosa de cada crime e das suas variações. Era o modelo tradicional. Através do segundo, a lei determina uma mesma pena geral a cada género ou espécie de delito para todas as suas diversíssimas variações. Este modelo, duro e bárbaro, faz claudicar a proporção entre os delitos e as penas, uma vez que ignora, na sua inflexibilidade, as circunstâncias de cada caso.

«Deve na lei fixar-se a pena relativamente não a cada delito individual, ou a cada uma das suas variações, mas sim a cada classe d'eles o género de pena geral correspondente, e de marcar ao mesmo tempo o ponto de extremo rigor, e o de maior brandura; pondo a escala de menor a maior; isto é, dos diversos graus de uma mesma pena, que se hajam de correr e subir entre o máximo e o mínimo à proporção das diferentes variações, e qualidades mais ou menos agravantes de um mesmo delito na sua espécie, não ficando assim arbítrio ao Juiz na escolha da pena, mas só na escolha do seu grau. (...) ficando assim aos Juízes tão somente a liberdade de escolher a escala, e escolher no intervalo, que há entre as duas extremidades, o grau de pena, que lhes parecer proporcionado às circunstâncias do delito: e neste sentido e prática é que os castigos podem ser arbitrários.» (RIBEIRO DOS SANTOS, 1814, pp.127 e 128)

Recusando quer o arbítrio absoluto quer os sistemas de pena legal inflexível, propõe o arbítrio restrito e limitado. A lei deve fixar para cada classe de crime o género de pena a aplicar, definindo o ponto de 
extremo rigor e o de maior brandura. Nesta solução, o juiz não escolhe a pena mas somente o respetivo grau.

\section{Nota final}

A antinomia entre legalidade e arbítrio judiciário pertence à época contemporânea e é uma herança do racionalismo jurídico. Até então, até o arbítrio se tornar sinónimo de incerteza e de despotismo, lei e arbítrio convivem de forma harmónica e complementar. No domínio penal, o arbitrium judicis esteve laboriosamente ao serviço da construção científica do direito, da adequação da lei às circunstâncias do caso concreto e às necessidades da política criminal. $\mathrm{O}$ arbítrio dos juízes não viveu num território estranho ao direito. Floresceu sob o império da lei. E fez florescer o direito.

Referências:

ALBUQUERQUE, Ruy e Martim de Albuquerque. História do Direito Português (1140-1415), Lisboa, Pedro Ferreira Editor, 2004. ALEXY, Robert. Conceito e Validade do Direito, São Paulo, Martins Fontes, 2009. ALONSO, Maria Paz, e António M. Hespanha. "Les peines dans les pays ibériques (XVII Recueils de la Société Jean Bodin, pour l'histoire comparative des institutions, Volume LVII, Terceira Parte (Europe depuis le XVIII siècle/Europe since the 18th century), Bruxelas, 1989, De Boeck Université, pp.195-225. AUSTIN, John. The Province of Jurisprudence Determined, Londres, John Murray, 1832. BARBAS HOMEM, António Pedro. Judex Perfectus. Função jurisdicional e estatuto judicial em Portugal (1640-1820), Coimbra, Almedina, 2003. BECCARIA, Cesare. Dos delitos e das penas (tradução de José de Faria Costa), Lisboa, Fundação Calouste Gulbenkian, 1998. BENTHAM, 
Jeremy. Traducção das Obras Politicas do Sabio Jurisconsulto Jeremias Bentham, vertidas do inglez na lingua portugueza por mandado do Soberano Congresso das Cortes Geraes, Tomo I. Theoria das Penas Legaes e Tomo II. Theoria dos Prémios Legaes, Lisboa, Imprensa Nacional, 1822. BERNAL, José Sánchez-Arcilla. El Arbitrio Judicial en el Antiguo Régimen (España e Indias, siglos XVI-XVIII), Madrid, Dykinson, 2012. BONGERT, Yvonne. Histoire du Droit Pénal. Cours de Doctorat, Paris, Panthéon-Assas, 2012. BRANDÃO, Cláudio. Tipicidade penal. Dos elementos da dogmática ao giro conceitual do método entimemático, Coimbra, Almedina, 2012. CARBASSE, JeanMarie. Introduction historique au droit pénal, Paris, P.U.F, 1990. CASTRO, Alfonso de. De potestate legis poenalis libri duo (edição facsimilada que reproduz a primeira edição de Salamanca, Andrea Portonariis), Madrid, Artes Gráficas Clavileño, 1961. CATARINA II da Rússia. Instructions adressées par Sa Majesté L'Impératrice de toutes les Russies A la Comission établie pour travailler à l'éxecution du projet d'un NOUVEAU CODE DE LOIS, São Petersburgo, 1769. CHARLES, Raymond. Histoire du droit pénal, Vendôme, P.U.F., 1976. CORREIA, Eduardo. "A evolução histórica das penas". Boletim da Faculdade de Direito da Universidade de Coimbra, LIII (1977), pp.51150. DELGADO DA SILVA, António. Collecção de Legislação Portugueza (1750-1762), Lisboa, Typografia Maigrense, 1830. DELGADO DA SILVA, António. Collecção de Legislação Portugueza (1763-1774), Lisboa, Typografia Maigrense, 1829. DELGADO DA SILVA, António. Collecção de Legislação Portugueza (1775-1790), Lisboa, Typografia Maigrense, 1828. DELGADO DA SILVA, António. Supplemento à Collecção de Legislação Portugueza (1750-1762), Lisboa, Typ. de Luiz Correa da Cunha, 1842. DELGADO DA SILVA, António. Supplemento à Collecção de Legislação Portugueza (1791 a 1820), Lisboa, Typ. de Luiz Correa da Cunha, 1847. ESMEIN, A. 
(Adhémar). Histoire de la procédure criminelle en France, Paris, L. Larose et Fercel, 1882. FILANGIERI, Gaetano. La Scienza della Legislazione, Volume I, Florença, Felice le Monnier, 1864. FOUCAULT, Michel. Les anormaux. Cours au Collège de France (1974-1975), Paris, Gallimard, 1999. FOUCAULT, Michel. Surveiller et punir. Naissance de la prison, Paris, Gallimard, 1975. GARRAUD, R. (René). Précis de Droit Criminel, Paris, Librairie de la Société Sirey, 1912. GILISSEN, John. "La preuve en Europe du XVIe au début du XIX siècle. Rapport de synthèse ". Recueils de la Société Jean Bodin pour l'Histoire comparative des institutions, XVII (La Preuve. Deuxième Partie. Moyen Age et temps modernes), Bruxelas, Librairie Encyclopédique, 1965, pp.755-833. GONZAGA, Tomás António. Tratado de Direito Natural. Carta sôbre a Usura - Minutas Correspondência - Documentos (edição crítica de M. Rodrigues Lapa). Obras Completas de Tomás António Gonzaga. II, Rio de Janeiro, Ministério da Educação e Cultura, Instituto Nacional do Livro, 1957. HESPANHA, António M. "Le Projet de Code pénal portugais de 1786. Un essai d'analyse structurelle”. La Leopoldina. Criminalità e giustizia criminale nelle riforme del '700 europeo, Volume 11. Le politiche criminali nel XVIII secolo (direcção de Luigi Berlinguer e Floriana Colao), Milão, Giuffrè, 1990, pp.387-448. HESPANHA, António Manuel. Cultura Jurídica Europeia. Síntese de um Milénio, Coimbra, Almedina, 2012. JOUSSE, M. (Daniel). Traité de la justice criminelle de France, Volumes I-IV, Paris, Debure père, 1771. KANTOROWICZ, Hermann. Der Kampf um die Rechtswissenschaft, Heildelberg, Winter, 1906 ("La lucha por la Ciencia del Derecho". Savigny, Kirchmann, Zitelmann, Kantorowicz. La Ciencia del Derecho, Buenos Aires, Losada, 1949, pp.323-373). KAUFMANN, Arthur. Introdução à Filosofia do Direito e à teoria da Direito Contemporâneas, Lisboa, Fundação Calouste Gulbenkian, 2009. 
KAUFMANN, Arthur. La Filosofía del Derecho en la Posmodernidad, Bogotá, Temis, 2007. KELSEN, Hans. Teoria Pura do Direito, Coimbra, Arménio Amado, 1984. LAINGUI, André. "La peine de mort au XVIII" siècle: opinion publique et réalités". La peine de mort. Droit, histoire, anthropologie, philosophie (direcção de Ioannis S. Papadopoulos e Jacques-Henri Robert), Paris, Panthéon Assas, 2000, pp.104-114. LAINGUI, André. "La sanction pénale dans le droit français du XVIII et XIX ${ }^{\mathrm{e}}$ siècle”. La Peine. Punishment. Recueils de la Société Jean Bodin, pour l'histoire comparative des institutions, Volume LVII, Terceira Parte (Europe depuis le XVIII siècle/Europe since the $18^{\text {th }}$ century), Bruxelas, De Boeck Université, 1989, pp.161-194. LAINGUI, André. La responsabilité pénale dans l'Ancien Droit (XVI-XVIII siècle), Paris, Pichon, 1970. LARDIZABAL Y URIBE, Manuel de. Discurso sobre las penas: contraído a las leyes criminales de España para facilitar su reforma, Madrid, Don Joachin Ibarra, Impresor de Camara de S. M., 1782. LARENZ, Karl. Metodologia da Ciência do Direito, Lisboa, Fundação Gulbenkian, 2005. LEBIGRE, Arlette. La justice du roi, Bruxelas, Complexe, 1995. MELLO FREIRE (dos Reis), Pascoal José de, Institutiones juris criminalis lusitani ou "Instituições de Direito Criminal Português" (tradução de Miguel Pinto de Meneses), Boletim do Ministério da Justiça, Lisboa, № 155 (1966), pp.43-202, e № 156 (1966) pp.66-168. MONTESQUIEU (CharlesLouis Secondat). De l'Esprit des Lois, Genebra, Barrilot \& Fils, 1748. NAVARRO DE PAIVA, José da Cunha. Estudos de direito penal, Paris-Lisboa, Aillaud \& Bertrand, s.d. NEGREIROS, João Tomás de. Introductiones ad Commentaria legum criminalium, quae in libro quinto ordinationum Lusitaniae continentur, Tomo I, Lisboa, Oficina Silviana (Regalibus Sylvianis, Regia Academiae), 1754. ORTEGO GIL, Pedro. "El fiscal de su majestad pide que se supla a mayores penas: defensa de la justicia y arbitrio judicial”. Initium: Revista Catalana 
d'Història del Dret, Associació Catalana d'Història del Dret 'Jaume de Montjuïc', № 5 (2000), pp.239-354. ORTEGO GIL, Pedro. "Notas sobre el arbitrio judicial usque ad mortem en el Antiguo Régimen". Cuadernos de historia del derecho, № 1 (2004) (Homenaje al Profesor Dr. D. José Manuel Pérez Muñoz-Arranco), pp.211-233. PEREIRA E SOUSA, Joaquim José Caetano. Classes dos Crimes, Lisboa, Regia Officina,1803. PEREIRA E SOUSA, Joaquim José Caetano. Esboço de hum Diccionario Juridico, Theoretico, e practico, Lisboa, Tomos I (AE) e II (F-Q), Typographia Rollandiana, 1825 e 1827; e Tomo III (RZ), Impressão Regia, 1827. PORRET, Michel. Le crime et ses circonstances. De l'esprit de l'arbitraire au siècle des Lumières selon les réquisitoires des procureurs généraux de Genève, Genebra, Droz, 1995. PORTALIS, Jean-Étienne-Marie. Discours, rapports et travaux inédits sur le Code Civil, Paris, Joubert, 1844. RENAUT, MarieHélène. Histoire du droit pénal, Paris, Ellipses, 2005. RIBEIRO DOS SANTOS, António. "Discurso sobre a Pena de Morte e Reflexões sobre alguns crimes". Jornal de Coimbra, № XXXIII, Parte II, Lisboa, Impressão Régia, 1814, pp.101-147. RIBEIRO DOS SANTOS, António. Notas ao Plano do Novo Codigo de Direito Publico de Portugal, Coimbra, Imprensa da Universidade, 1844. Riforma della Legislazione Criminale negli Stati di S.A.R. Il Gran-Duca di Toscana, Veneza, 1787. ROUSSEAU, Jean-Jacques. Du Contrat Social, Amesterdão, Chez Marc Michel Rey,1762. SAVIGNY, Friedrich Carl von. Vom Beruf unsrer Zeit für Gesetzgebung und Rechtswissenschaft, Heidelberg, Mohr und Zimmer, 1814 (Da la Vocación de Nuestro Siglo para la Legislación y la Ciencia del Derecho, Buenos Aires, Atalaya, 1946). SCHAFFSTEIN, Federico. La Ciencia europea del Derecho Penal en la época del humanismo, Madrid, Instituto de Estudios Politicos, 1957. SCHNAPPER, Bernard. "Les peines arbitraires du XIII ${ }^{\mathrm{e}}$ au XVIII siècle (doctrines savantes et usages français)" (Tijdschrift voor 
Rechtsgeschiedenis. Revue d'histoire du droit. The Legal History Review, T.41, 1973, pp.237-277; e T.42, 1974, pp.81-112), Paris, Librairie générale de droit et de jurisprudence, 1974. THORILLON. Idées sur les Loix Criminelles, Tomos I e II, Paris, Belin-Froullé-Petit, 1788. TIRAQUEAU. De Poenis Temperandis (Introdução, tradução e notas de André Laingui), Paris, Economica, 1986. TOMÁS Y VALIENTE, Francisco. "Teoria y practica de la tortura judicial en las obras de Lorenzo y Sanz (1618-1680)". Anuario Historia del Derecho Español, XLI (1971), pp.439-485. TOMÁS Y VALIENTE, Francisco. El Derecho penal de la Monarquia Absoluta (siglos XVI, XVII y XVIII), Madrid, Tecnos, 1992. VANGUERVE CABRAL, António. Pratica judicial, muyto util, e necessaria para os que principiaó os officios de julgar, e advogar e para todos os que solicitaó causas nos Auditorios de hum, e outro foro, Coimbra, Officina de Antonio Simoens Ferreira, 1730. VILLEY, Michel. Philosophie du droit. Définitions et fins du droit. Les moyens du droit, Paris, Dalloz, 2006. VILLEY, Michel. Réflexions sur la philosophie et le droit. Les Carnets, Paris, PUF, 1995. VOLTAIRE. Commentaire sur le livre des délits et des peines, Genebra, 1767. VOUGLANS, Muyart de. Les lois criminelles de France dans leur ordre naturel, Tomos I e II, Paris, Neuchâtel: Société Typographique, 1781. 